\title{
Salvianolic Acid A Protects H9c2 Cells from Arsenic Trioxide-Induced Injury via Inhibition of the MAPK Signaling Pathway
}

\author{
Jing-yi Zhang ga,b,c,d Gui-bo Sun ${ }^{a, b, c, d}$ Yun Luo $o^{a, b, c, d}$ Min Wang ${ }^{a, b, c, d} \quad$ Wei Wang ${ }^{a}$ \\ Yu-yang Du $u^{a, b, c, d}$ Ying-li Yu $u^{a, b, c, d}$ Xiao-bo Sun ${ }^{a, b, c, d}$

\begin{abstract}
Institute of Medicinal Plant Development, Peking Union Medical College and Chinese Academy of Medical Sciences, Beijing, ${ }^{b}$ Beijing Key Laboratory of Innovative Drug Discovery of Traditional Chinese Medicine (Natural Medicine) and Translational Medicine, Beijing, 'Key Laboratory of Bioactive Substances and Resource Utilization of Chinese Herbal Medicine, Ministry of Education, Beijing, 'Key Laboratory of efficacy evaluation of Chinese Medicine against glyeolipid metabolism disorder disease, State Administration of Traditional Chinese Medicine, Beijing, China
\end{abstract}

\section{Key Words}

Arsenic trioxide $\bullet$ Salvianolic acid A • Cardiotoxicity • Oxidative stress $•$ Apoptosis $\bullet$ MAPK

\begin{abstract}
Background/Aims: This study aimed to investigate whether Salvianolic acid A (Sal A) conferred cardiac protection against Arsenic trioxide (ATO)-induced cardiotoxicity in H9c2 cells by inhibiting MAPK pathways activation. Methods: H9c2 cardiac cells were exposed to $10 \mu \mathrm{M}$ ATO for $24 \mathrm{~h}$ to induce cytotoxicity. The cells were pretreated with Sal A for $4 \mathrm{~h}$ before exposure to ATO. Cell viability was determined utilizing the MTT assay. The percentage of apoptosis was measured by a FITC-Annexin V/PI apoptosis kit for flow cytometry. Mitochondrial membrane potential $(\Delta \Psi \mathrm{m})$ was detected by JC-1. The intracellular ROS levels were measured using an Image-i T $^{\mathrm{TM}}$ LIVE Green Reactive Oxygen Species Detection Kit. The apoptosis-related proteins and the MAPK signaling pathways proteins expression were quantified by Western blotting. Results: Sal A pretreatment increased cell viability, suppressed ATO-induced mitochondrial membrane depolarization, and significantly altered the apoptotic rate by enhancing endogenous antioxidative enzyme activity and ROS generation. Signal transduction studies indicated that Sal A suppressed the ATO-induced activation of the MAPK pathway. More importantly, JNK, ERK, and p38 inhibitors mimicked the cytoprotective activity of Sal A against ATO-induced injury in $\mathrm{H} 9 \mathrm{c} 2$ cells by increasing cell viability, up-regulating $\mathrm{Bcl}-2$ protein expression, and down-regulating both Bax and caspase-3 protein expression. Conclusion: Sal A decreases the ATO-induced apoptosis and necrosis of $\mathrm{H} 9 \mathrm{c} 2$ cells, and the underlying mechanisms of this protective effect of Sal A may be connected with the MAPK pathways.




\section{Cellular Physiology Cell Physiol Biochem 2017;41:1957-1969

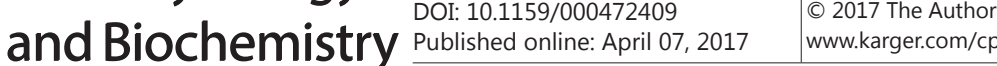 \\ Zhang et al.: Salvianolic Acid A Protects H9c2 Cells From Apoptosis}

\section{Introduction}

Arsenicals have been used in traditional Chinese mineral medicine for approximately 2400 years. Arsenic trioxide (ATO) has recently been deemed as an effective form of antineoplastic therapy, especially for relapsed or refractory acute promyelocytic leukemia [1]. In 2000, the Food and Drug Administration approved ATO application as a treatment for APL [2]. However, the clinical application of ATO is limited by its cardiotoxicity, as it induces T-wave changes, QT prolongation, torsades de pointes, and sudden cardiac death in humans [3-5]. A specific and effective treatment to reduce ATO therapy cardiotoxicity is currently unavailable. DNA fragmentation, excessive reactive oxygen species (ROS) generation, intracellular calcium overload, cardiac ion channel changes, and apoptosis are strongly related to ATO-induced cytotoxicity [6-8]. ROS overproduction is a crucial toxic mechanism of ATO. Therefore, we hypothesized that the application of antioxidant phytochemicals could prevent ATO-induced cardiotoxicity. Chinese herbal medicine is a good source of potent, safe, and affordable bioactive compounds for cardioprotection. Therefore, an antioxidant agent that can lower ATO cardiotoxicity and improve clinical curative effects from traditional Chinese medicine is indispensable.

Radix salviae Miltiorrhiza is a multi-purpose medicinal plant that has been commonly used for cardiovascular diseases for centuries. Salvianolic acids have been proven to possess effective antioxidants and radical scavenging capabilities because of their polyphenolic structure [9]. Salvianolic acids also protect cardiomyocytes against drug-induced cardiotoxicity through their ROS scavenging ability. In an animal model of doxorubicininduced toxicity, salvianolic acids protected the myocardium by reducing oxidative stress [10]. Among the salvianolic acids, salvianolic acid A (Sal A) has the most potent antioxidant activity [11]. Sal A reduced ventricular fibrillation, lactate dehydrogenase (LDH) leakage, and lipid peroxidation in damaged cardiac tissues of an ischemia/reperfusion injury model [12]. Furthermore, intravenous administration of Sal A markedly attenuates cardiac dysfunction and myocardial injury caused by isoproterenol and enhances mitochondrial respiratory function in myocardial infarction in rats [13]. These findings have prompted us to study whether Sal A can prevent ATO-induced cardiotoxicity. A recent study associated arsenicinduced cardiac cell death with MAPK activation [14]. Therefore, whether Sal A activates MAPKs to suppress ATO-induced cardiac injury requires verification.

The present study aimed to determine the protective effect of Sal A against ATO-induced cardiotoxicity in H9c2 cells and explain its potential molecular mechanisms related to the MAPK pathway.

\section{Materials and Methods}

\section{Chemicals and materials}

Sal A (purity > 98\%; molecular structure shown in Fig. 1) was purchased from Shanghai Winherb Medical S \& T Development Co., Ltd. (Shanghai, China). ATO was obtained from Harbin YI-DA Pharmaceutical Ltd. (Harbin, China). 3-(4,5-Dimethylthiazol-2-yl)-2,5-diphenyltetrazolium bromide (MTT) was purchased from Sigma-Aldrich (St. Louis, MO, USA). The kits for testing the lactate dehydrogenase (LDH) and malondialdehyde (MDA) contents and the superoxide dismutase (SOD), catalase (CAT), glutathione peroxidase (GSH-PX) activities were obtained from Nanjing Jiancheng Institute of Biological Engineering (Nanjing, China). The fluorescent dye JC-1 was purchased from Sigma-Aldrich (St. Louis, MI). ROS fluorometric assay kits were acquired from BioVision (CA, USA). An annexin V/propidium iodide (PI) apoptosis detection kit was obtained from Invitrogen (Eugene, OR, USA). All primary antibodies were obtained from Santa Cruz Biotechnology (Santa Cruz, CA, USA). The horseradish peroxidase (HRP)-conjugated secondary antibodies were purchased from CWbiotech (Beijing, China). PD98059, SB203580 and SP600125 were purchased from Selleckchem (Houston, TX, USA). All chemical reagents were at least of analytical grade. 


\section{Cellular Physiology Cell Physiol Biochem 2017;41:1957-1969 \begin{tabular}{l|l} 
and $10.1159 / 000472409$ & $\begin{array}{l}\text { () 2017 The Author(s). Published by S. Karger AG, Basel } \\
\text { www.karger.com/cpb }\end{array}$
\end{tabular} \\ Zhang et al.: Salvianolic Acid A Protects H9c2 Cells From Apoptosis}

Cell culture and treatment

H9c2 rat ventricular cardiomyocytes were obtained from the Cell Bank of the Chinese Academy of Sciences (Shanghai, China) and cultured as previously described [15]. The cells were subcultured after reaching 70\%-80\% confluency. For all experiments, cells were plated at an appropriate density in accordance with the experimental design and then grown for $36 \mathrm{~h}$ before the experiment. H9c2 cells were pretreated with the indicated concentrations $(2.5,5$, and $10 \mu \mathrm{M})$ of Sal A for $4 \mathrm{~h}$ and then treated with ATO $(10 \mu \mathrm{M})$ alone for $24 \mathrm{~h}$.
Fig. 1. The molecular structure of Sal A.

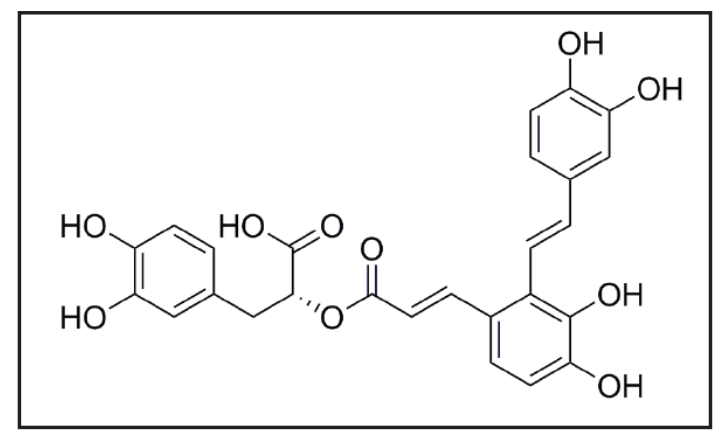

\section{Cell viability analysis}

Cell viability was measured using the MTT assay, as previously reported [16]. In brief, H9c2 cells were seeded in 96-well plates at a density of $1 \times 10^{4}$ cells/well. After $4 \mathrm{~h}$ of pretreatment with different doses of Sal A, the cells were washed to remove Sal A, and then they were treated with $10 \mu \mathrm{M}$ ATO for $24 \mathrm{~h}$. Subsequently, $1 \mathrm{mg} / \mathrm{mL}$ MTT solution was added to each well, and the cells were incubated for 3-4 h at 37 ${ }^{\circ} \mathrm{C}$. The supernatant was removed, and the insoluble MTT-formazan salt in each well was then dissolved in $150 \mu \mathrm{L}$ of DMSO. The absorbance was measured at $570 \mathrm{~nm}$ using a microplate reader (SpectraFluor, TECAN, Sunrise, Austria).

\section{LDH release assay}

H9c2 cells were seeded in 6 -well plates at $3 \times 10^{5}$ cells/well. The cells were pretreated with different concentrations of Sal A for $4 \mathrm{~h}$ before ATO was added in place of Sal A. After incubation for $24 \mathrm{~h}$, the supernatant was collected to measure LDH release with an LDH assay kit according to the manufacturer's instructions.

\section{FITC-Annexin V/PI apoptosis assay}

The percentage of early apoptosis and necrosis was measured using a FITC-Annexin V/PI apoptosis kit for flow cytometry according to the manufacturer's instructions (Invitrogen). Cells were pretreated with Sal A for $4 \mathrm{~h}$, which was then washed out before adding $10 \mu \mathrm{M}$ ATO and the cells incubated for $24 \mathrm{~h}$. After drug treatment, the cells were harvested, washed twice with cold phosphate buffered saline (PBS), and then incubated with $5 \mu \mathrm{L}$ of FITC-Annexin V and $1 \mu \mathrm{L}$ of PI working solution $(100 \mu \mathrm{g} / \mathrm{mL})$ for 15 min in the dark at room temperature. Cellular fluorescence was measured by flow cytometry analysis using a flow cytometer (FACSCalibur, BD Biosciences, CA, USA).

\section{Autophagy detection}

For live cell analysis via flow cytometry, follow the general protocol for the Cyto-ID ${ }^{\mathrm{rm}}$ Autophagy Detection Kit(Enzo Life Sciences). H9c2 cells incubated with different concentrations of ATO for $24 \mathrm{~h}$ or incubated with $10 \mu \mathrm{M}$ ATO for different time. Then the cells should be centrifuged at $300 \mathrm{~g}$ for $5 \mathrm{~min}$ and the pellet should be resuspended in $500 \mu \mathrm{L}$ of freshly diluted Cyto-ID ${ }^{\mathrm{TM}}$ Green Detection Reagent in $1 \times$ assay buffer ( $1 \mu \mathrm{L}$ of reagent per $4 \mathrm{~mL}$ of $1 \times$ assay buffer). Incubate the cells for $30 \mathrm{~min}$ at room temperature in the dark and the stained cells should be immediately analyzed via a flow cytometer (FACSCalibur, BD Biosciences, CA, USA).

Measurement of mitochondrial membrane potential $(\triangle \Psi m)$ via JC-1

JC-1 (Invitrogen, USA) was used to detect the mitochondrial transmembrane potential changes caused by Sal A. After the treatments, cells were collected, washed with PBS, and then incubated with $2 \mu \mathrm{M} \mathrm{JC}-1$ in the dark for $30 \mathrm{~min}$ at $37^{\circ} \mathrm{C}$ following the manufacturer's instructions. Cells were washed twice with PBS and then analyzed by a flow cytometer (FACSCalibur Flow Cytometer, BD Biosciences, USA).

Generation of ROS

To explore the effect of Sal A on the intracellular and mitochondrial ROS levels, cells were pretreated with Sal A for $4 \mathrm{~h}$ and then washed before adding $10 \mu \mathrm{M}$ ATO and incubating for $24 \mathrm{~h}$. Then, the cells 


\section{Cellular Physiology Cell Physiol Biochem 2017;41:1957-1969

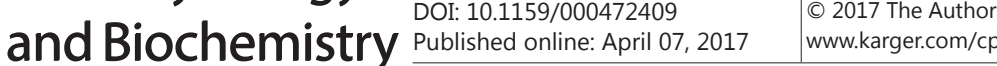

Zhang et al.: Salvianolic Acid A Protects H9c2 Cells From Apoptosis

were harvested and washed with $1 \times$ wash buffer. The cells were centrifuged at $400 \times g$ for 5 min at room temperature, and the supernatant was discarded. Intracellular ROS levels were measured using an ImageiT $^{\mathrm{TM}}$ LIVE Green Reactive Oxygen Species Detection Kit according to the manufacturer's instructions (Enzo Life Sciences, Farmingdale, NY, USA). The cells were resuspended in $400 \mathrm{~mL}$ of the $25 \mathrm{mM}$ carboxy-H2DCFDA working solution, incubated in the dark for $20-30 \mathrm{~min}$ at $37^{\circ} \mathrm{C}$, and then analyzed via flow cytometry. The mitochondrial ROS levels were measured using MitoSOX ${ }^{\mathrm{TM}}$ Red mitochondrial superoxide indicator (Invitrogen, Molecular Probes). After treatment, the cells were suspended in warm PBS and incubated with $5 \mu \mathrm{M}$ MitoSOX reagent for $10 \mathrm{~min}$ at $37^{\circ} \mathrm{C}$ in the dark. The cells were then washed three times with PBS, and the mitochondrial ROS levels were analyzed using flow cytometry.

Measurement of the activities of SOD, CAT and GSH-Px

H9c2 cells were cultured in 6 -well plates with $3 \times 10^{5}$ cells/well. After treatment, the cells were collected to measure the SOD, CAT, and GSH-Px activities with the corresponding detection kits according to the manufacturer's instructions.

Western blot analysis

H9c2 cells were pretreated with Sal A (10 $\mu \mathrm{M}$ for $4 \mathrm{~h}$ ), PD98059 (50 $\mu \mathrm{M}$ for $30 \mathrm{~min}$ ), SB203580 (5 $\mu \mathrm{M}$ for $1 \mathrm{~h}$ ) or SP600125 (25 $\mu \mathrm{M}$ for $30 \mathrm{~min})$. The cells were then washed and incubated with ATO $(10 \mu \mathrm{M})$ for $24 \mathrm{~h}$. Then, the cells were harvested, washed with PBS, and lysed for 30 min on ice using mammalian protein extraction kits containing 1\% phenylmethylsulfonyl fluoride (CoWin Bioscience Co., Ltd., Beijing, China). The mitochondrial and cytosolic fractions were separated via a Cell Mitochondrial Isolation Kit (Beyotime, Haimen, China) according to the manufacturer's instructions. The protein concentration was measured with a BCA kit (Pierce Corporation, Rockford, IL, USA). Equal amounts of protein were fractionated using $10 \%$ sodium dodecyl sulfate polyacrylamide gels and electrotransferred onto nitrocellulose membranes (Millipore Corporation, Bedford, MD, USA) in Tris-glycine buffer at $100 \mathrm{~V}$ for $55 \mathrm{~min}$ in an ice box. Membranes were blocked for at least $2 \mathrm{~h}$ in $5 \%$ skim milk at room temperature and then incubated overnight with the primary antibodies $(1: 200)$ at $4{ }^{\circ} \mathrm{C}$. After washing with Tris-buffered saline and Tween 20 (TBST) for $30 \mathrm{~min}$, the membranes were incubated with the appropriate HRP-conjugated secondary antibodies for $2 \mathrm{~h}$ at room temperature. The membranes were washed three times for $30 \mathrm{~min}$ on a shaking table and then visualized with enhanced chemiluminescence solution. The different protein expression levels were determined using Molecular Imager Lab (Bio-Rad, USA).

\section{Statistical analysis}

The data were expressed as the mean \pm SD of at least three independent experiments. Statistical comparisons between different groups were performed using a one-way ANOVA or the Student-NewmanKeuls method with GraphPad Prism 5.0 (SPAA, Inc., Chicago, USA). A value of $p<0.05$ was considered statistically significant.

\section{Results}

Effects of Sal A on the viability of H9c2 cells

We initially evaluated the general toxicity of ATO. Cell viability was measured via the MTT assay. The cells were treated with a series of ATO concentrations $(2.5,5,10,20$, and 40 $\mu \mathrm{M}$ ) for $24 \mathrm{~h}$. As shown in Fig. $2 \mathrm{~A}$, cell viability was down by $57.92 \% \pm 2.86 \%$ at $10 \mu \mathrm{M}$ ATO compared with that in the control group; similar observations were made in a previous report [7]. Therefore, this study used $10 \mu \mathrm{M}$ ATO in further experiments. The cytotoxic effects of Sal A on H9c2 cells were then evaluated. After treatment with various concentrations (2.5-10 $\mu \mathrm{M}$ ) of Sal A alone for $4 \mathrm{~h}$, no change in cell viability was detected by the MTT assay (Fig. 2B).

The capacity of Sal A to protect against ATO-induced H9c2 cellular injury was assessed. $\mathrm{H} 9 \mathrm{c} 2$ cells were pretreated with the indicated Sal A concentrations for $4 \mathrm{~h}$ and then washed and incubated with ATO $(10 \mu \mathrm{M})$ for $24 \mathrm{~h}$. As shown in Fig. 2C, pretreatment with different doses of Sal A for $4 \mathrm{~h}$ significantly increased cell viability in a concentration-dependent manner, compared with exposure to $10 \mu \mathrm{M}$ ATO alone. These results indicate that Sal A 


\section{Cellular Physiology Cell Physiol Biochem 2017;41:1957-1969

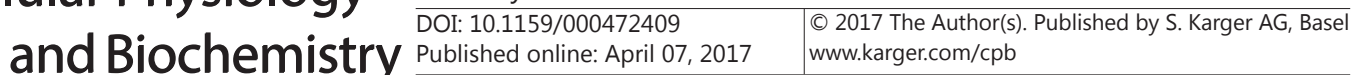
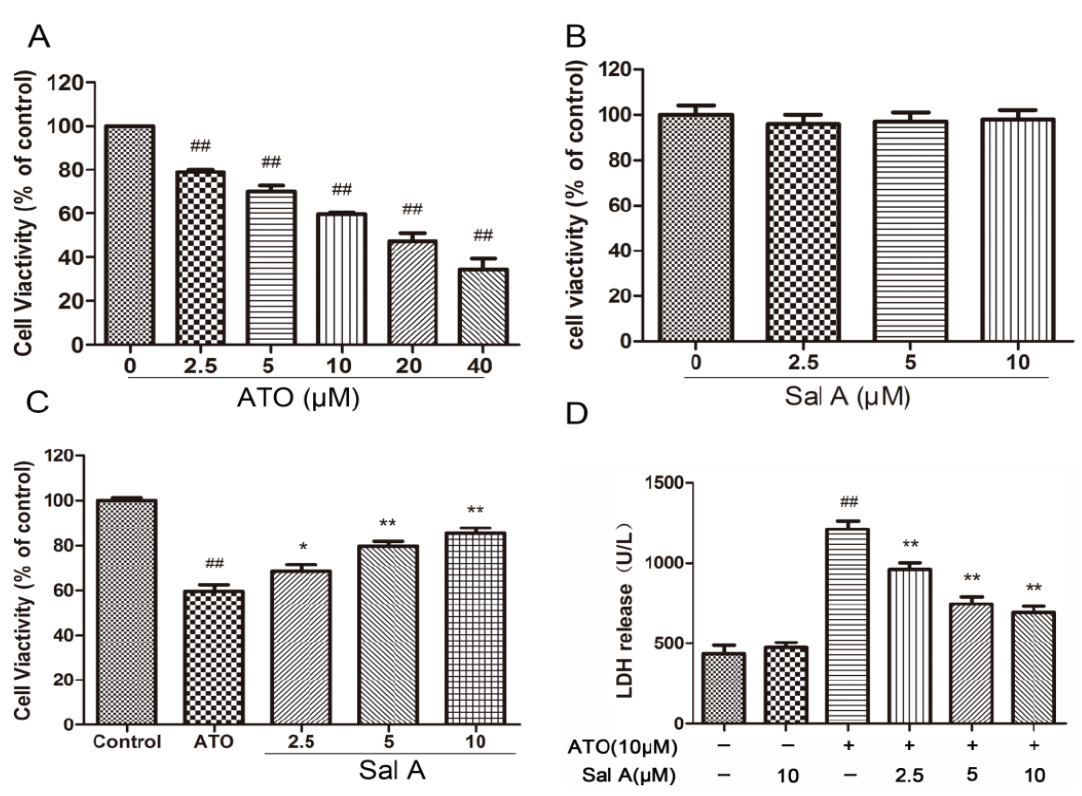

Fig. 2. Individual effects of ATO and Sal A on cell viability, and the effects of Sal A on ATO-induced H9c2 cell injury. Cell viability was measured through MTT assays. (A) Cells were treated with ATO $(2.5-40 \mu \mathrm{M})$ alone for $24 \mathrm{~h}$. (B) The cells were incubated with Sal A (2.5-10 $\mu \mathrm{M}$ ) alone for $4 \mathrm{~h}$. (C) H9c2 cells were pretreated with the indicated Sal A concentrations for $4 \mathrm{~h}$ and then washed. Then, ATO $(10 \mu \mathrm{M})$ was added for $24 \mathrm{~h}$. (D) H9c2 cardiomyocytes were preincubated with Sal A for $4 \mathrm{~h}$ followed by treatment with ATO (10 $\mu \mathrm{M})$ alone for $24 \mathrm{~h}$. The effect of Sal A pretreatment on the amount of LDH released by H9c2 cells was measured via the LDH assay kit. The data are expressed as the mean \pm SD of three independent experiments. \#\#p $<0.01$ versus control; ${ }^{*} \mathrm{p}<0.05$ versus ATO-treated cells; ${ }^{* *} \mathrm{p}<0.01$ versus ATO-treated cells.
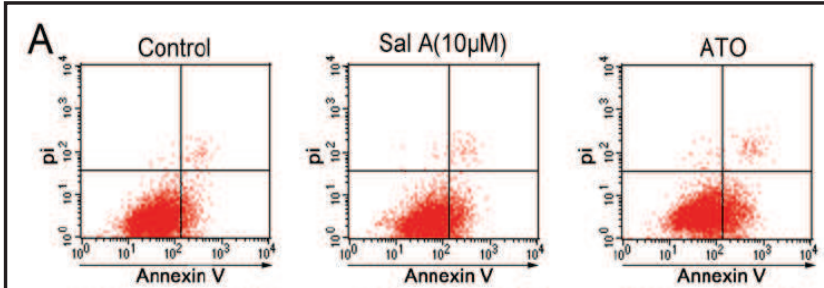

B
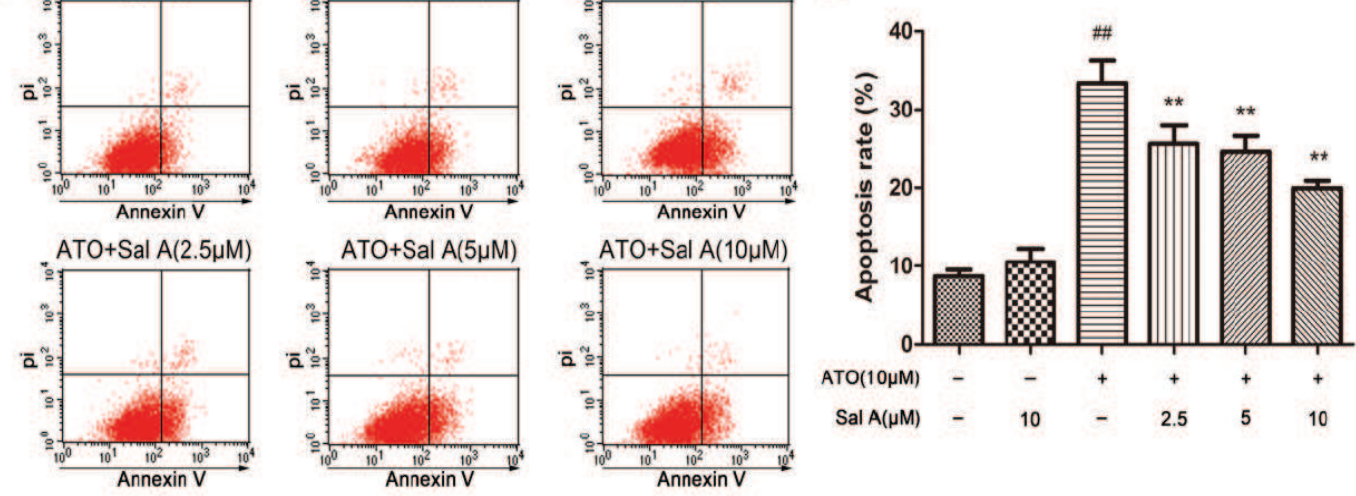

Fig. 3. Effects of Sal A on ATO-induced apoptosis in H9c2 cells. H9c2 cells were pretreated with the indicated Sal A concentrations for $4 \mathrm{~h}$ and then washed. The cells were subsequently incubated with ATO $(10 \mu \mathrm{M})$ for $24 \mathrm{~h}$, which was followed by flow cytometry analysis of the FITC-Annexin V/PI staining in the cells. (A)Flow cytometry analysis of the apoptosis data. (B) Statistical analysis of the flow cytometry data. The data are presented as the mean \pm SD of three independent experiments. ${ }^{\# \# p}<0.01$ versus control; ${ }^{* *} \mathrm{p}<0.01$ versus ATO-treated cells. Sal A treatment decreased ATO-induced apoptosis in H9c2 cells.

can protect H9c2 cells from ATO-induced cell injury, with $10 \mu \mathrm{M}$ being the most efficient concentration.

\section{KARGER}




\section{Cellular Physiology Cell Physiol Biochem 2017;41:1957-1969 \begin{tabular}{l|l|l} 
DOI: 10.1159/000472409 & () 2017 The Author(s). Published by S. Karger AG, Basel \\
and Biochemistry
\end{tabular} \\ Zhang et al.: Salvianolic Acid A Protects H9c2 Cells From Apoptosis}

A
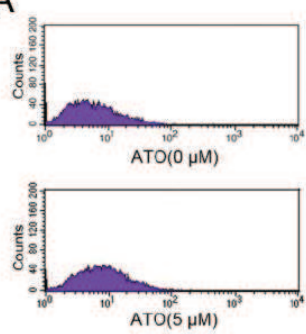

B
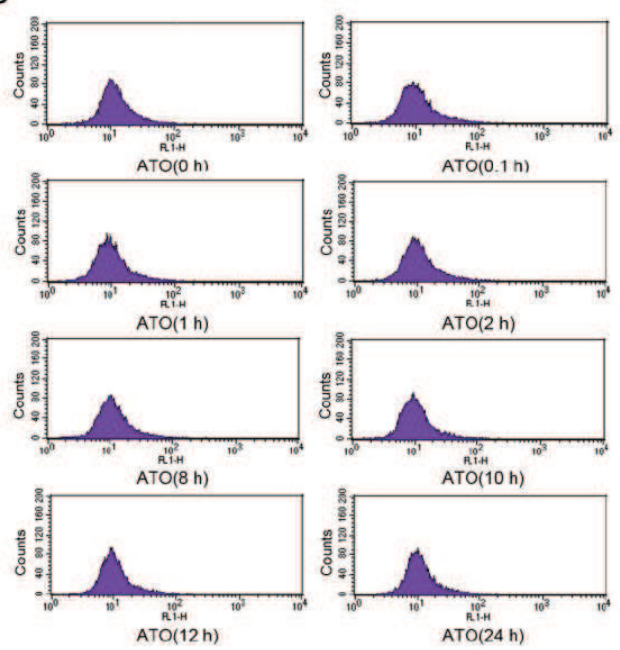

ATO(0.1 $\mathrm{n}$

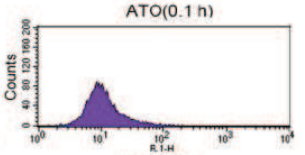

ATO( $(2 \mathrm{~h})$
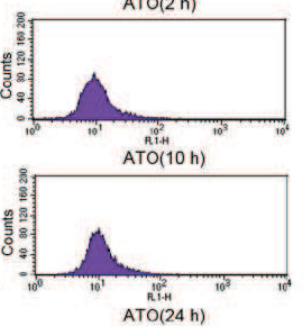
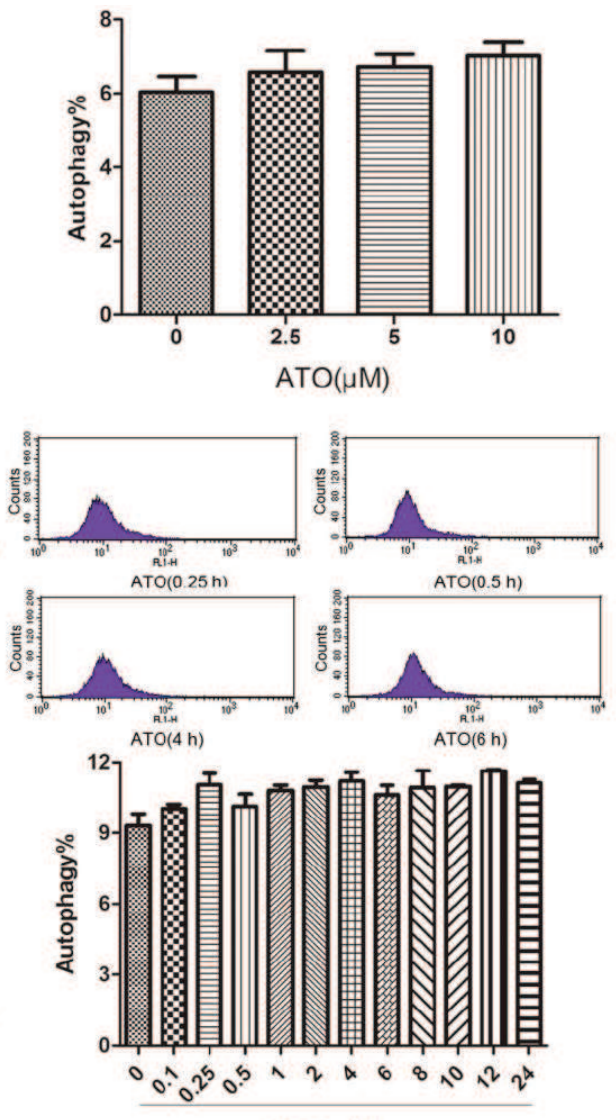

Time (h)

Fig. 4. Effects of ATO treatment on autophagy level in H9c2 cells. (A) Effects of ATO (2.5-10 $\mu \mathrm{M})$ treatment for $24 \mathrm{~h}$ on autophagy level. (B) Effects of $10 \mu \mathrm{M}$ ATO $(0-24 \mathrm{~h})$ treatment on autophagy level. Autophagy induction was detected by flow cytometry analysis of cells incubated with CytoID green fluorescent probes, which detected autophagic vacuoles. The summarized data showing the percentage of cells that were positive for CytoID fluorescence $(n=3)$. Data are presented as the mean \pm SD of three independent experiments.

LDH leakage, which is a biomarker of cell death, was also detected. Briefly, H9c2 cardiomyocytes were preincubated with Sal A for $4 \mathrm{~h}$, which was followed by treatment with ATO $(10 \mu \mathrm{M})$ alone for $24 \mathrm{~h}$. As shown in Fig. 2D, $10 \mu \mathrm{M}$ ATO treatment for $24 \mathrm{~h}$ significantly increased LDH release of H9c2 cells. However, LDH release conspicuously decreased when the cells were pre-incubated with Sal A (2.5-10 $\mu \mathrm{M})$ for $4 \mathrm{~h}$. The protection of Sal A against ATO-induced cytotoxicity was similar to that determined by the MTT assay.

Effects of Sal A on cell apoptosis

The anti-apoptotic effect of Sal A was confirmed by measuring the percentage of early apoptosis and necrosis through the FITC-Annexin V/PI apoptosis assay. As shown in Fig. 3, ATO treatment increased the apoptotic rate in H9c2 cells, but this effect was significantly alleviated by pretreatment with different Sal A concentrations.

Effects of ATO on cell autophagy

The effects of ATO in different concentrations and treatment times on cardiomyocyte autophagy were also evaluated. As shown in Fig. 4, only a slight increase in autophagy levels was observed both in cells treated with ATO $(0-10 \mu \mathrm{M})$ alone for $24 \mathrm{~h}$ and in the cells treated with $10 \mu \mathrm{M}$ ATO alone for 0-24 h. Taken together, we conclude that ATO induces, at most, only slight autophagy in $\mathrm{H} 9 \mathrm{c} 2$ cells. 


\section{Cellular Physiology Cell Physiol Biochem 2017;41:1957-1969 \begin{tabular}{ll|l} 
and Biochemistry & DOb: 10.1159/000472409 & $\begin{array}{l}\text { P 2017 The Author(s). Published by S. Karger AG, Basel } \\
\text { www.karger.com/cpb }\end{array}$ \\
\hline
\end{tabular}

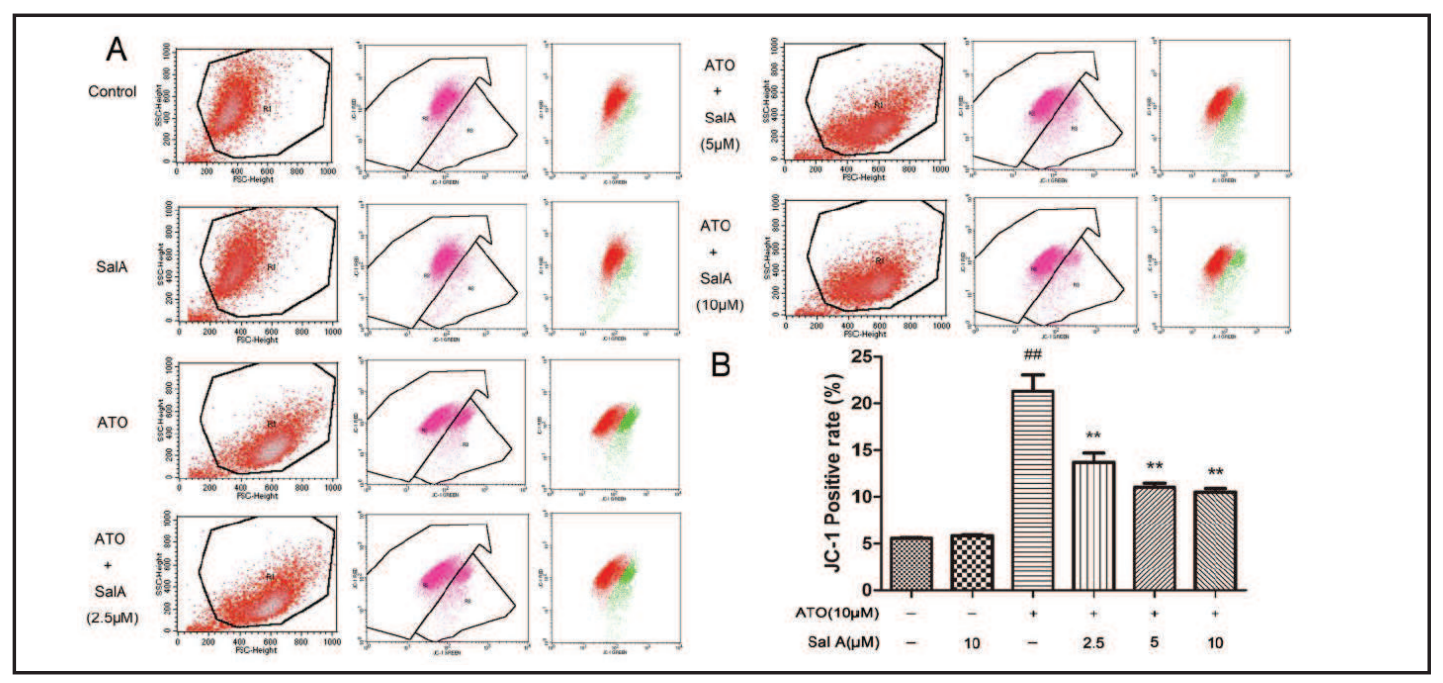

Fig. 5. Effects of Sal A on mitochondrial transmembrane potential. H9c2 cells were pretreated with the indicated Sal A concentrations for $4 \mathrm{~h}$ and then washed. The cells were subsequently incubated with ATO $(10 \mu \mathrm{M})$ for $24 \mathrm{~h}$, which was followed by flow cytometry analysis of the mitochondrial membrane potential of H9c2 cells through JC-1 staining. (A)Flow cytometry analysis and the gating parameters of the JC-1 data. (B) Statistical analysis of the flow cytometry data. The data are presented as the mean \pm SD of three independent experiments. ${ }^{\# \#} \mathrm{p}<0.01$ versus control; ${ }^{* *} \mathrm{p}<0.01$ versus ATO-treated cells.

\section{Effects of Sal A on mitochondrial membrane potential ( $\triangle \Psi m)$}

ATO exerts a rapid noxious effect on mitochondria [17]. Decreased $\Delta \Psi \mathrm{m}$ implies membrane depolarization and can trigger mitochondrion-dependent apoptosis. Consistent with previous work [17], the present study showed that $\Delta \Psi \mathrm{m}$ decreased in ATO-treated cells, as shown by the fluorescence shift from the upper left to lower right of the panel. As shown in Fig. 5, Sal A can protect the mitochondrial membrane against $\Delta \Psi \mathrm{m}$ loss induced by $10 \mu \mathrm{M}$ ATO. The evident protective effects of Sal A on the mitochondria revealed that the mitochondria is one of the target organelles of ATO in cardiomyocytes.

\section{Effects of Sal A on ROS production and the activities of SOD, CAT, and GSH-PX}

Excess generation of ROS during cell injury leads to cellular damage and apoptosis [18]. As shown in Fig. 6A, ATO significantly increased intracellular ROS levels compared with the control, whereas Sal A pretreatment attenuated the ATO-induced ROS generation in $\mathrm{H} 9 \mathrm{c} 2$ cells in a dose-dependent manner. The intracellular accumulation of superoxide was estimated using MitoSOX ${ }^{\mathrm{TM}}$ Red, which selectively targets the mitochondria, where it is oxidized by superoxide dismutase and exhibits red fluorescence upon binding to nucleic acids. Similar to $\mathrm{H}_{2}$ DCFDA, flow cytometric data showed that Sal A pretreatment significantly attenuated the ATO-induced mitochondrial ROS level increase (Figs. 6B). These results indicate that ROS generation is involved in the protection by Sal A against ATO-induced cell injury.

We measured the activities of SOD, CAT, and GSH-Px to determine the endogenous antioxidant capacity of H9c2 cells. As shown in Fig. 6C, ATO decreased the SOD, CAT, and GSH-Px activities, but Sal A pretreatment effectively reversed this effect in a dose-dependent manner. These results indicate that Sal A protects cells against oxidative stress injury by enhancing the antioxidant capacity of the cells.

Sal A modulated the expressions of apoptosis-related proteins in ATO-treated H9c2 cells

Western blot analysis was performed in $\mathrm{H} 9 \mathrm{c} 2$ cells to investigate the protective mechanism of Sal A pretreatment on apoptosis regulation after ATO exposure. The Bcl-2 family of proteins, including Bcl-2, Bax, Bad, and Bcl-xl, plays an important role in ATOinduced cardiomyocyte apoptosis [19]. As shown in Fig. 7, ATO treatment decreased Bcl-2 


\section{Cellular Physiology Cell Physiol Biochem 2017;41:1957-1969 \begin{tabular}{c|l|l} 
DOI: 10.1159/000472409 & () 2017 The Author(s). Published by S. Karger AG, Basel
\end{tabular}

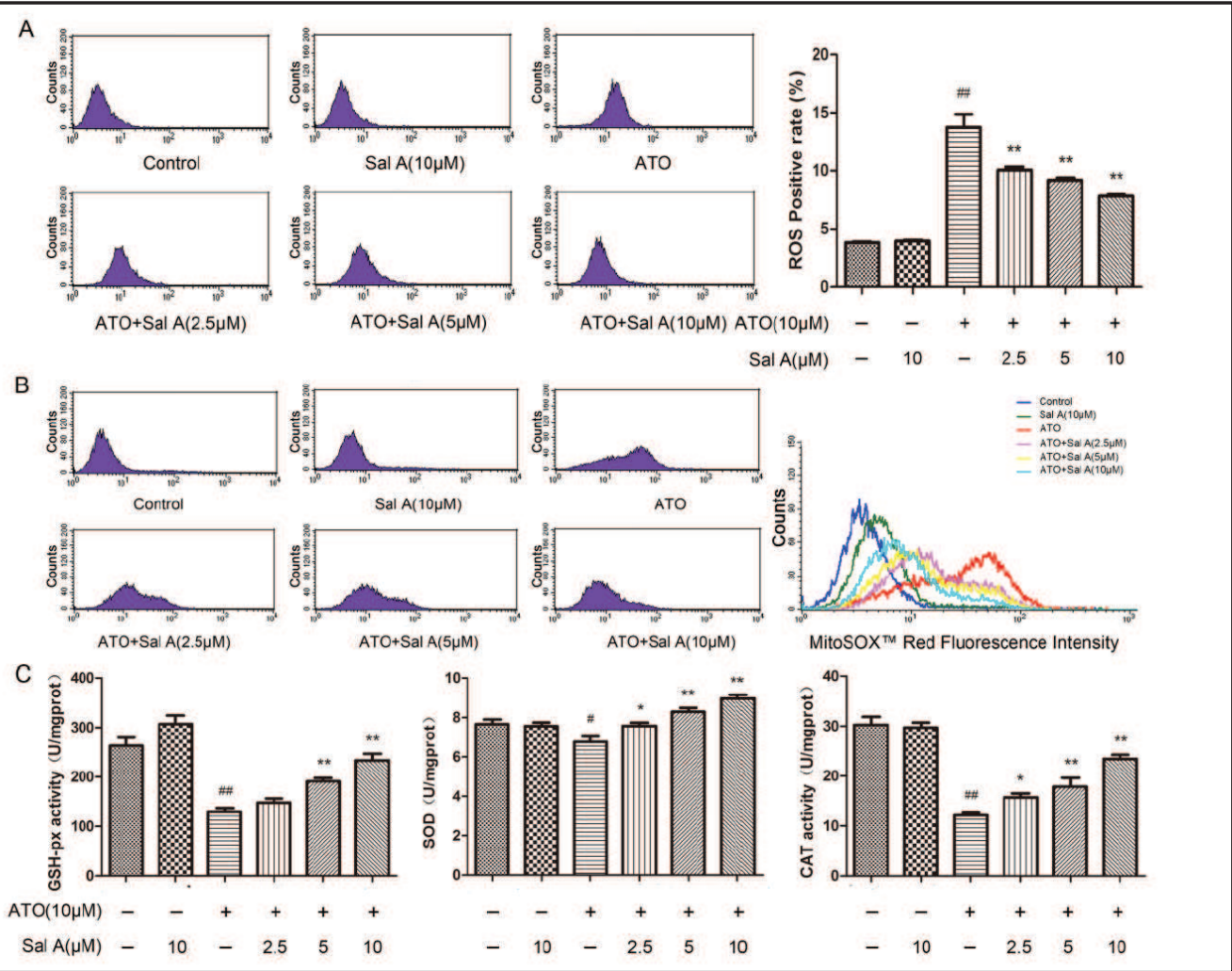

Fig. 6. Effects of Sal A treatment on ROS levels and antioxidant enzyme activities in H9c2 cells. H9c2 cells were pretreated with the indicated Sal A concentrations for $4 \mathrm{~h}$ and were then washed. The cells were subsequently incubated with ATO $(10 \mu \mathrm{M})$ for $24 \mathrm{~h}$. The effects of Sal A on (A) cellular ROS levels, (B) mitochondrial ROS levels, and (C) GSH-Px activity, SOD activity, and CAT activity in H9c2 cells. The data are presented as the mean \pm SD of three independent experiments. ${ }^{*} p<0.05$ versus control; $\#$ p $<0.01$ versus control; ${ }^{*} \mathrm{p}<0.05$ versus ATO-treated cells; ${ }^{* *} \mathrm{p}<0.01$ versus ATO-treated cells.

protein expression and increased Bax protein expression compared with the control, but pretreatment with Sal A blocked these changes. Sal A increased the Bcl-2/Bax ratio and Bcl-xl expression and decreased Bad expression. Moreover, ATO up-regulated caspase-3 and caspase- 9 expression levels, but Sal A pretreatment inhibited these increases. Sal A pretreatment also inhibited the ATO-induced increase in PARP1 expression. ATO induced cyt-c release, which is an important indicator of apoptosis [20], from the mitochondria to the cytoplasm, whereas Sal A pretreatment inhibited its release. These results suggest that Sal A can up-regulate anti-apoptotic protein expression levels and down-regulate expression of pro-apoptotic proteins to protect against myocardial apoptosis.

\section{Sal A exerts its effects by activating the MAPK pathway}

The MAPK pathway is associated with multiple cellular processes, including cell proliferation and survival. ATO-induced cardiac cell death is associated with MAPK activation [21]. To further investigate the role of the MAPK signaling pathway in the anti-apoptotic effects of Sal A, the levels of expression of MAPK proteins, including ERK, p38 kinase, and JNK, were examined on the basis of their phosphorylation levels relative to their total protein expression. ATO treatment activated the MAPK pathway (Fig. 8A). However, Sal A significantly decreased the ratios of p-JNK/JNK, p-ERK/ERK, and p-p38/p38 compared with ATO treatment.

The effects of Sal A on the combined MAPK signaling transduction pathways were confirmed using the ERK-specific inhibitor PD98059, p38-specific inhibitor SB203580, and 


\section{Cellular Physiology Cell Physiol Biochem 2017;41:1957-1969 \begin{tabular}{l|l|l} 
DOI: 10.1159/000472409 & () 2017 The Author(s). Published by S. Karger AG, Basel
\end{tabular} \\ Zhang et al.: Salvianolic Acid A Protects H9c2 Cells From Apoptosis}

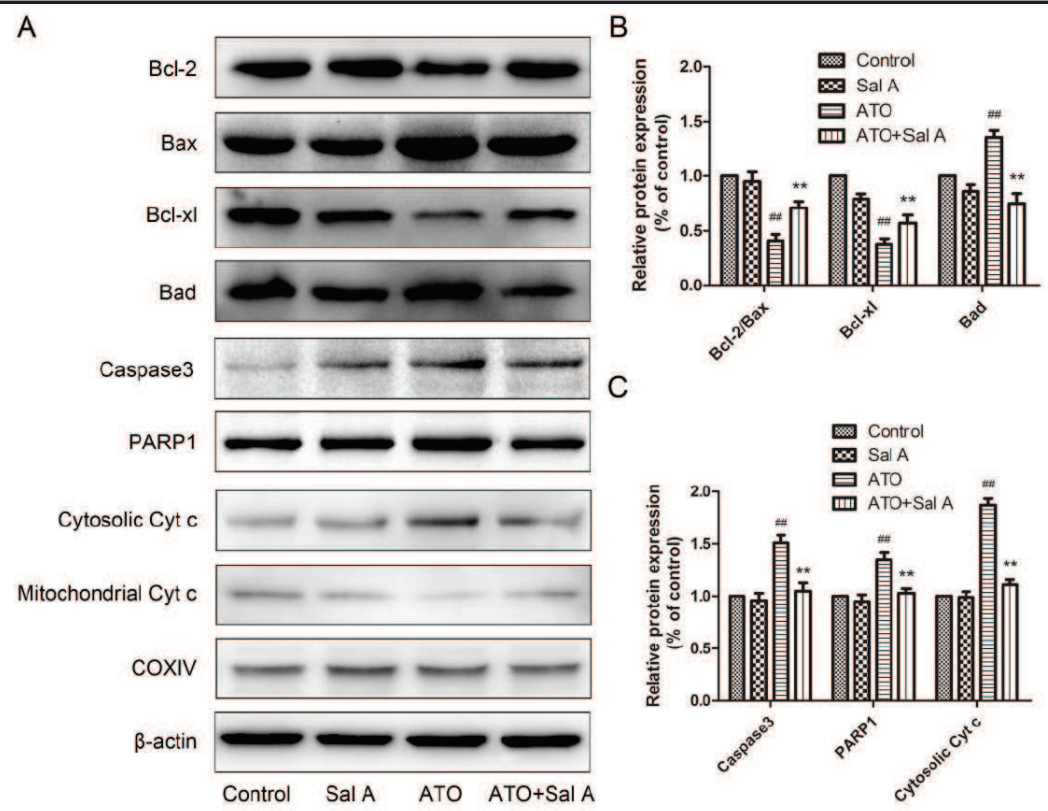

Fig. 7. Effects of Sal A on apoptosis-related protein expression in ATO-treated H9c2 cells. H9c2 cells were pretreated with the indicated Sal A concentrations for $4 \mathrm{~h}$ and were then washed. The cells were subsequently incubated with ATO $(10 \mu \mathrm{M})$ for $24 \mathrm{~h}$. (A) The effects of ATO and Sal A on the Bcl-2 family and the caspase protein family. (B) The Bcl-2/Bax expression ratio, Bcl-xl expression level, and Bad expression level in $\mathrm{H} 9 \mathrm{c} 2$ cells were assayed by western blot analysis with a gel-pro analyzer. (C) Expression levels of caspase-3, PARP, and cytosolic cyt-c in H9c2 cells were assayed by western blot analysis with a Gel-Pro Analyzer. The data are presented as the mean \pm SD of three independent experiments. ${ }^{\# \#} \mathrm{p}<0.01$ versus control; ${ }^{* *} \mathrm{p}<$ 0.01 versus ATO-treated cells.

JNK-specific inhibitor SP98059. As shown in Figs. 8B and 8C, pretreatment of H9c2 cells with these inhibitors alone blocked MAPK pathway activation, significantly increasing the cell viability and the Bcl-2/Bax ratio, and decreased the ATO-induced expression of cleaved caspase-3. These results suggest that the protective effect of Sal A against ATO-induced apoptosis in H9c2 cardiomyocytes partially relies on the inhibition of MAPK signaling pathways.

\section{Discussion}

ATO is a naturally occurring arsenic compound with dramatic efficacy in treating acute promyelocytic leukemia (APL) [22,23]. Despite its remarkable effects on certain cancer types, ATO has adverse effects, such as cardiac toxicity; thus, its clinical applications are restricted [24-26]. ATO cardiotoxicity is known to proceed by $\mathrm{As}^{3+}$ binding to sulfhydryl groups of proteins, thereby damaging the mitochondrial respiratory chain and generating excessive ROS, eventually leading to myocardial cell apoptosis $[27,28]$. In line with previous reports, we showed that ATO treatment can increase ROS production and decrease antioxidant enzyme activity in cardiomyocytes. Therefore, ATO induces oxidative stress in myocardial cells by producing ROS and inhibiting the intrinsic protective antioxidant capacity [2931]. Consequently, a compound that can decrease ROS overproduction and also prevent cardiomyocyte apoptosis is of great interest to improve the adverse effects of ATO.

Considerable evidence has revealed that Sal A is effective for cardiovascular therapy and is a potent antioxidant against peroxidative damage to biomembranes [32,33]. In the current study, Sal A pretreatment for $4 \mathrm{~h}$ attenuated ATO-induced H9c2 cardiomyocyte 


\section{Cellular Physiology \\ Cell Physiol Biochem 2017;41:1957-1969 \begin{tabular}{c|l}
\hline DOI: 10.1159/000472409 & ( ) 2017 The Author(s). Published by S. Karger AG, Basel \\
and Biochemistry
\end{tabular} \\ Zhang et al.: Salvianolic Acid A Protects H9c2 Cells From Apoptosis}
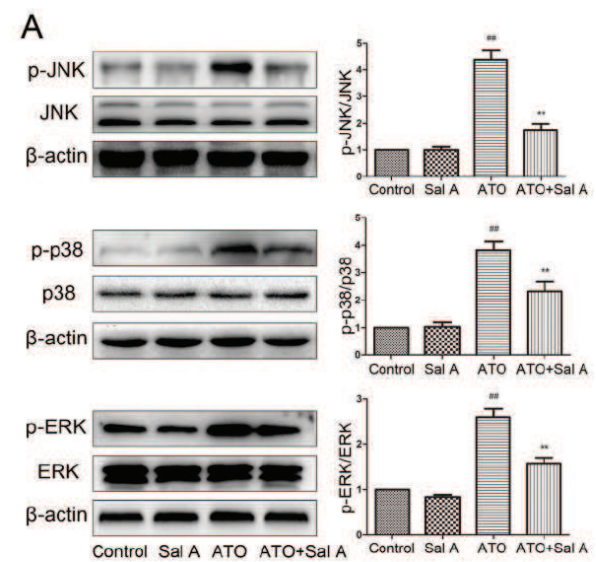
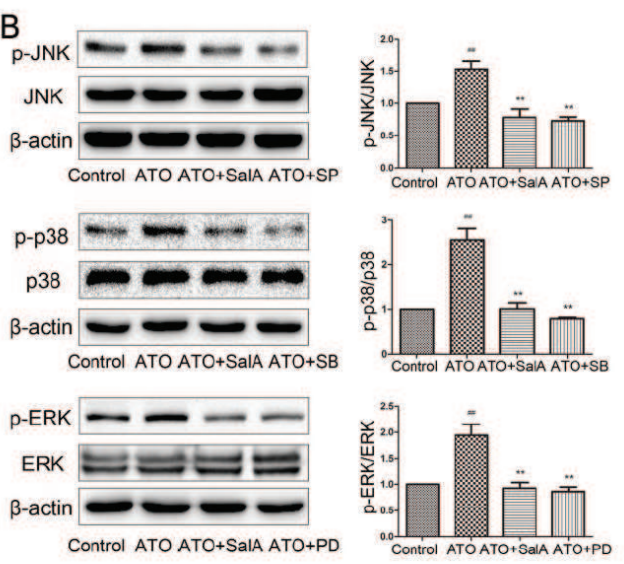

C
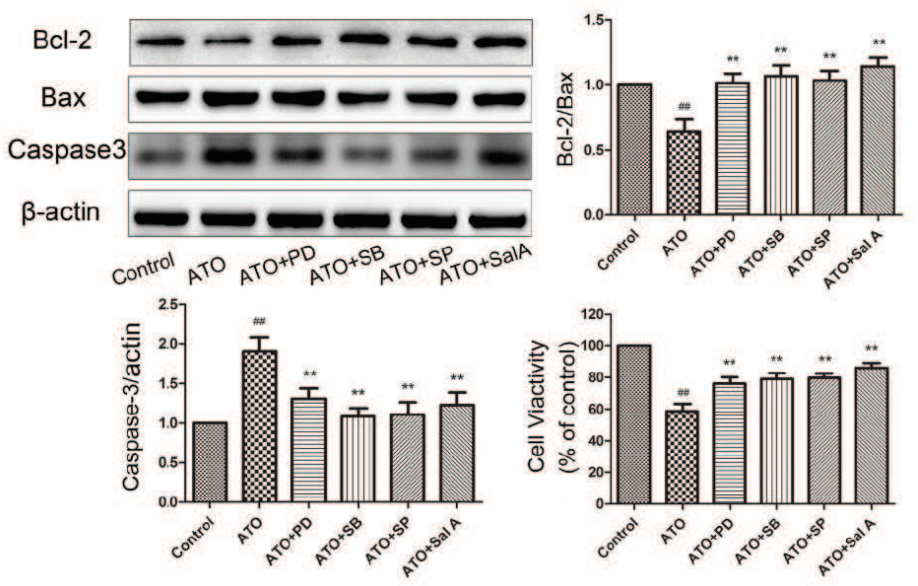

Fig. 8. Effects of ATO and Sal A on the MAPK signaling pathways. Specific kinase inhibitors were used to confirm the protective effects of Sal A on the MAPK pathways. H9c2 cells were pretreated with Sal A (10 $\mu \mathrm{M}$ for $4 \mathrm{~h}$ ), PD98059 (40 $\mu \mathrm{M}$ for $30 \mathrm{~min}$ ), SB203580 (5 $\mu \mathrm{M}$ for $1 \mathrm{~h}$ ) or SP600125 (25 $\mu \mathrm{M}$ for $30 \mathrm{~min}$ ) and then washed. The cells were subsequently incubated with ATO $(10 \mu \mathrm{M})$ for $24 \mathrm{~h}$. (A) The expression levels of phosphorylated and total ERK1/2, p38, and JNK were detected by western blot analysis. (B and C) The effects of PD98059 (an ERK1/2-specific inhibitor), SB203580 (a p38-specific inhibitor) and SP600125 (a JNK-specific inhibitor) on the MAPK pathways, Bcl-2/Bax expression ratio, caspase- 3 activation, and cell viability. The data are presented as the mean \pm SD of three independent experiments. ${ }^{\# \# p}<0.01$ versus control; ${ }^{* *} \mathrm{p}<0.01$ versus ATO-treated cells.

injury, increased cell viability, decreased LDH leakage, and modulated the cardiomyocyte redox state by increasing the activities of antioxidant enzymes (GSH-Px, SOD, and CAT) that were inhibited after ATO treatment.

ATO-induced oxidative stress leads to mitochondrial dysfunction and cardiomyocyte apoptosis, both of which contribute to myocardial injury development [34]. The hyperpolarization of damaged mitochondrial membranes initiates opening of the MPTP, mitochondrial translocation of Bcl-2 and Bax, and release of cyt-c. In contrast, Sal A pretreatment strongly attenuated ATO-induced mitochondrial damage. Numerous studies have also suggested that the $\mathrm{Bcl}-2 / \mathrm{Bax}$ ratio determines the cellular threshold for apoptosis [35]. Sal A pretreatment enhanced anti-apoptotic Bcl-2 and Bcl-xl expression levels but reduced those of pro-apoptotic Bax and Bad. Caspase-3 is thought to initiate cell apoptosis. Caspase-3 leads to DNA fragmentation and other morphological changes that are consistent with cell death [36]. PARP is an important indicator of caspase-3 activation [37]. In the present study, ATO treatment significantly up-regulated caspase-3 and PARP levels; Sal A 


\section{Cellular Physiology Cell Physiol Biochem 2017;41:1957-1969

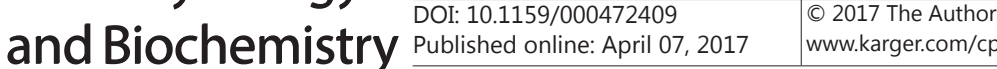 \\ Zhang et al.: Salvianolic Acid A Protects H9c2 Cells From Apoptosis}

pretreatment reversed this effect. This result indicates that the anti-apoptotic effect of Sal A is mediated by caspase-3. Based on the data, Sal A might provide protection by balancing the Bcl-2 and Bax ratio, preventing the mitochondria from releasing cyt-c and ultimately inhibiting caspase-3 expression.

The MAPK pathways, which include ERK1/2, JNK, and p38 MAPK, are vital mediators of oxidative stress-induced apoptosis. MAPK activation is involved in ATO-induced tumor cells and cardiac cell death $[14,38,39]$. Consequently, we hypothesized that the protective effect of Sal A against ATO-induced apoptosis in H9c2 cells is related to MAPK signaling cascades. As expected, Sal A pretreatment inhibited the phosphorylation of JNK, ERK1/2, and p38. To assess whether the protective effect of Sal A is related to MAPK inhibition, we blocked the MAPK signaling pathway with a JNK inhibitor (SP98059), a p38 inhibitor (SB203580), and an ERK inhibitor (PD98059). The pretreatment of cells with these inhibitors alone had similar cardioprotective effects compared with Sal A. Therefore, Sal A may suppress ATOinduced cell apoptosis at least partially by modulating the MAPK signaling pathways.

The role of autophagy in ATO-induced cardiotoxicity remains controversial. However, our results are similar to those found for ATO exposure in HL-1 mouse trial cardiomyocytes [40]; only a slight activation of autophagy was observed, thereby suggesting the differential reactions of apoptosis and autophagy to ATO toxicity.

\section{Conclusion}

Our findings suggest that Sal A protects H9c2 cells from ATO-induced cardiac toxicity, as shown by increased cell viability, decreased LDH leakage, enhanced antioxidant enzyme activities, the attenuated overproduction of ROS, stabilized $\Delta \Psi \mathrm{m}$, down-regulated Bax expression, and up-regulated Bcl-2 expression in cells. The protective effect of Sal A against ATO-induced H9c2 cell apoptosis is dependent on the MAPK signaling pathway. These results suggest that the combination of Sal A and ATO is potentially beneficial in protecting against ATO-induced cardiotoxicity.

Nevertheless, this study is in its initial stages, and the results of the in vitro cell experiments still need to be verified in animal models. A more thorough investigation is necessary to further explore the mechanisms of Sal A against ATO-induced cardiotoxicity.

\section{Acknowledgements}

This work was supported by the Major Scientific and Technological Special Project for 'Significant New Drugs Formulation' (Grant No. 2012ZX09501001-004) and the Special Project for National Traditional Chinese Medicine Industry of China (Grant No. 201507004)

\section{Disclosure Statement}

No conflict of interest declared.

\section{References}

-1 Sanz MA, Grimwade D, Tallman MS, Lowenberg B, Fenaux P, Estey EH, Naoe T, Lengfelder E, Buchner T, Dohner H, Burnett AK, Lo-Coco F: Management of acute promyelocytic leukemia: Recommendations from an expert panel on behalf of the European LeukemiaNet. Blood 2009;113:1875-1891.

-2 Antman KH: Introduction: The history of arsenic trioxide in cancer therapy. Oncologist 2001;6:1-2.

-3 Barbey JT, Soignet S: Prolongation of the QT interval and ventricular tachycardia in patients treated with arsenic trioxide for acute promyelocytic leukemia. Ann Intern Med 2001;135:842-843. 


\section{Cellular Physiology Cell Physiol Biochem 2017;41:1957-1969 \begin{tabular}{l|l} 
and Biochemistry Publisned onlne: AprIIU7, 2017 & $\begin{array}{l}\text { () 2017 The Author(s). Published by S. Karger AG, Basel } \\
\text { www.karger.com/cpb }\end{array}$
\end{tabular}}

Zhang et al.: Salvianolic Acid A Protects H9c2 Cells From Apoptosis

4 Unnikrishnan D, Dutcher JP, Varshneya N, Lucariello R, Api M, Garl S, Wiernik PH, Chiaramida S: Torsades de pointes in 3 patients with leukemia treated with arsenic trioxide. Blood 2001;97:1514-1516.

-5 Westervelt P, Brown RA, Adkins DR, Khoury H, Curtin P, Hurd D, Luger SM, Ma MK, Ley TJ, DiPersio JF: Sudden death among patients with acute promyelocytic leukemia treated with arsenic trioxide. Blood 2001;98:266-271.

6 Chang SI, Jin B, Youn P, Park C, Park JD, Ryu DY: Arsenic-induced toxicity and the protective role of ascorbic acid in mouse testis. Toxicol Appl Pharmacol 2007;218:196-203.

7 Zhao XY, Li GY, Liu Y, Chai LM, Chen JX, Zhang Y, Du ZM, Lu YJ, Yang BF: Resveratrol protects against arsenic trioxide-induced cardiotoxicity in vitro and in vivo. Br J Pharmacol 2008;154:105-113.

8 Das AK, Sahu R, Dua TK, Bag S, Gangopadhyay M, Sinha MK, Dewanjee S: Arsenic-induced myocardial injury: Protective role of Corchorus olitorius leaves. Food Chem Toxicol 2010;48:1210-1217.

-9 Sun Y, Zhu H, Wang J, Liu Z, Bi J: Isolation and purification of salvianolic acid a and salvianolic acid B from Salvia miltiorrhiza by high-speed counter-current chromatography and comparison of their antioxidant activity. J Chromatogr B Analyt Technol Biomed Life Sci 2009;877:733-737.

10 Sun Y, Zhu H, Wang J, Liu Z, Bi J: Isolation and purification of salvianolic acid a and salvianolic acid B from Salvia miltiorrhiza by high-speed counter-current chromatography and comparison of their antioxidant activity. J Chromatogr B Analyt Technol Biomed Life Sci 2009;877:733-737.

-11 Ho JH, Hong CY: Salvianolic acids: Small compounds with multiple mechanisms for cardiovascular protection. J Biomed Sci 2011;18:30.

12 Liu GT, Zhang TM, Wang BE, Wang YW: Protective action of seven natural phenolic compounds against peroxidative damage to biomembranes. Biochem Pharmacol 1992;43:147-152.

13 Wang SB, Tian S, Yang F, Yang HG, Yang XY, Du GH: Cardioprotective effect of salvianolic acid a on isoproterenol-induced myocardial infarction in rats. Eur J Pharmacol 2009;615:125-132.

14 Miao X, Tang Z, Wang Y, Su G, Sun W, Wei W, Li W, Miao L, Cai L, Tan Y, Liu Q: Metallothionein prevention of arsenic trioxide-induced cardiac cell death is associated with its inhibition of mitogen-activated protein kinases activation in vitro and in vivo. Toxicol Lett 2013;220:277-285.

-15 Sun X, Sun GB, Wang M, Xiao J, Sun XB: Protective effects of cynaroside against H2O2-induced apoptosis in H9c2 cardiomyoblasts. J Cell Biochem 2011;112:2019-2029.

- 16 Sun B, Sun GB, Xiao J, Chen RC, Wang X, Wu Y, Cao L, Yang ZH, Sun XB: Isorhamnetin inhibits H2O2-induced activation of the intrinsic apoptotic pathway in H9c2 cardiomyocytes through scavenging reactive oxygen species and ERK inactivation. J Cell Biochem 2012;113:473-485.

17 Vineetha VP, Prathapan A, Soumya RS, Raghu KG: Arsenic trioxide toxicity in H9c2 myoblasts--damage to cell organelles and possible amelioration with Boerhavia diffusa. Cardiovasc Toxicol 2013;13:123-137.

18 Sinha K, Das J, Pal PB, Sil PC: Oxidative stress: The mitochondria-dependent and mitochondria-independent pathways of apoptosis. Arch Toxicol 2013; 87:1157-1180.

19 Mahieux R, Pise-Masison C, Gessain A, Brady JN, Olivier R, Perret E, Misteli T, Nicot C: Arsenic trioxide induces apoptosis in human T-cell leukemia virus type 1- and type 2-infected cells by a caspase-3dependent mechanism involving Bcl-2 cleavage. Blood 2001;98:3762-3769.

20 Wang M, Sun G, Sun X, Wang H, Meng X, Qin M, Sun J, Luo Y, Sun X: Cardioprotective effect of salvianolic acid $\mathrm{B}$ against arsenic trioxide-induced injury in cardiac H9c2 cells via the PI3K/Akt signal pathway. Toxicol Lett 2013;216:100-107.

21 Miao X, Tang Z, Wang Y, Su G, Sun W, Wei W, Li W, Miao L, Cai L, Tan Y, Liu Q: Metallothionein prevention of arsenic trioxide-induced cardiac cell death is associated with its inhibition of mitogen-activated protein kinases activation in vitro and in vivo. Toxicol Lett 2013;220:277-285.

22 Xu WX, Liu SZ, Wu D, Qiao GF, Yan J: Sumoylation of the tumor suppressor promyelocytic leukemia protein regulates arsenic Trioxide-Induced collagen synthesis in osteoblasts. Cell Physiol Biochem 2015;37:15811591.

23 Cyranoski D: Arsenic patent keeps drug for rare cancer out of reach of many. Nat Med 2007;13:1005.

24 Yeh ET, Bickford CL: Cardiovascular complications of cancer therapy: Incidence, pathogenesis, diagnosis, and management. J Am Coll Cardiol 2009;53:2231-2247.

25 Drolet B, Simard C, Roden DM: Unusual effects of a QT-prolonging drug, arsenic trioxide, on cardiac potassium currents. Circulation 2004;109:26-29.

26 Zhao X, Shi YQ, Yan CC, Feng PF, Wang X, Zhang R, Zhang X, Li BX: Up-regulation of miR-21 and miR-23a contributes to As203 -induced hERG channel deficiency. Basic Clin Pharmacol Toxicol 2015;116:516-523. 


\section{Cellular Physiology Cell Physiol Biochem 2017;41:1957-1969 \begin{tabular}{l|l|l}
\cline { 2 - 2 } DOI: 10.1159/000472409 & () 2017 The Author(s). Published by S. Karger AG, Basel
\end{tabular} and Biochemistry Published onIne: April07, 2017 www.karger.com/cpb}

Zhang et al.: Salvianolic Acid A Protects H9c2 Cells From Apoptosis

27 Ralph SJ: Arsenic-based antineoplastic drugs and their mechanisms of action. Met Based Drugs 2008;2008:260146.

-28 Bessho M, Aki T, Funakoshi T, Unuma K, Noritake K, Kato C, Uemura K: Rho-kinase inhibitor Y-27632 attenuates arsenic trioxide toxicity in H9c2 cardiomyoblastoma cells. Cardiovasc Toxicol 2013;13:267-277.

29 Kumazaki M, Ando H, Sasaki A, Koshimizu TA, Ushijima K, Hosohata K, Oshima Y, Fujimura A: Protective effect of alpha-lipoic acid against arsenic trioxide-induced acute cardiac toxicity in rats. J Pharmacol Sci 2011;115:244-248.

-30 Vineetha VP, Soumya RS, Raghu KG: Phloretin ameliorates arsenic trioxide induced mitochondrial dysfunction in H9c2 cardiomyoblasts mediated via alterations in membrane permeability and ETC complexes. Eur J Pharmacol 2015;754:162-172.

- 31 Vineetha VP, Girija S, Soumya RS, Raghu KG: Polyphenol-rich apple (Malus domestica L.) peel extract attenuates arsenic trioxide induced cardiotoxicity in H9c2 cells via its antioxidant activity. Food Funct 2014;5:502-511.

-32 Qiang G, Yang X, Shi L, Zhang H, Chen B, Zhao Y, Zu M, Zhou D, Guo J, Yang H, Zhang L, Du G: Antidiabetic Effect of Salvianolic Acid a on Diabetic Animal Models via AMPK Activation and Mitochondrial Regulation. Cell Physiol Biochem 2015;36:395-408.

-33 Xing JJ, Chen X, Tu PF, Jiang Y, Zhao JY: Effects of salvianolic acids on erythrocyte deformability in oleic acid induced acute lung injury in rabbits. Clin Hemorheol Microcirc 2006;34:507-517.

-34 Zhu X, Zuo L: Characterization of oxygen radical formation mechanism at early cardiac ischemia. Cell Death Dis 2013;4:e787.

35 Wang M, Si J, Yu Y, Gao M, Zhang J, Xing X, Liu Y, Sun G, Sun X: Red clover flavonoids protect against oxidative stress-induced cardiotoxicity in vivo and in vitro. RSC Adv 2014;4:54668-54676.

-36 Janicke RU, Sprengart ML, Wati MR, Porter AG: Caspase-3 is required for DNA fragmentation and morphological changes associated with apoptosis. J Biol Chem 1998;273:9357-9360.

37 Ai Q Sun G, Luo Y, Dong X, Hu R, Meng X, Sun X: Ginsenoside Rb1 prevents hypoxia-reoxygenation-induced apoptosis in H9c2 cardiomyocytes via an estrogen receptor-dependent crosstalk among the Akt, JNK, and ERK 1/2 pathways using a label-free quantitative proteomics analysis. RSC Adv 2015;5:26346-26363.

- 38 Davison K, Mann KK, Waxman S, Miller WJ: JNK activation is a mediator of arsenic trioxide-induced apoptosis in acute promyelocytic leukemia cells. Blood 2004;103:3496-3502.

-39 Eguchi R, Fujimori Y, Takeda H, Tabata C, Ohta T, Kuribayashi K, Fukuoka K, Nakano T: Arsenic trioxide induces apoptosis through JNK and ERK in human mesothelioma cells. J Cell Physiol 2011;226:762-768.

40 Watanabe M, Funakoshi T, Unuma K, Aki T, Uemura K: Activation of the ubiquitin-proteasome system against arsenic trioxide cardiotoxicity involves ubiquitin ligase Parkin for mitochondrial homeostasis. Toxicology 2014;322:43-50. 